\title{
Avaliação do Efeito da Adição de Microcápsulas Probióticas Às Características Físico-Químicas, Microbiológicas e Sensoriais de Salame Tipo Italiano
}

\author{
Pablo Teixeira da Silva (I), Leadir Lucy Martins Fries (I), Cristiano \\ Ragagnin de Menezes (I), Juliana de Oliveira Bastos (I), Daniele \\ Juçara Kleovan Lang (II), Janaína de Borba Braga (II)
}

(I) UFSM - Universidade Federal de Santa Maria (Avenida Roraima, no 1000, CEP: 97105-900, Santa Maria/RS), (II) UFSM - Universidade Federal de Santa Maria (Linha Sete de Setembro, s/n, CEP: 98400-000, Frederico Westphalen/RS)

\section{Resumo}

A microencapsulação pode ser definida como a tecnologia de empacotamento de compostos, com filmes poliméricos, formando microcápsulas. Os micro-organismos têm sido microencapsulados em alimentos devido ao efeito bactericida do suco gástrico, aumentando, assim, sua viabilidade ao longo do trato gastrointestinal. Os probióticos são definidos como micro-organismos vivos capazes de melhorar o equilíbrio intestinal, produzindo efeitos benéficos à saúde. Devido ao fato de que os produtos cárneos fermentados serem fabricados com carne crua e consumidos sem prévio aquecimento, o uso de probióticos mostra-se promissor. Entretanto, estes produtos possuem um ambiente não favorável para a sobrevivência de probióticos em razão de características como baixo pH e atividade de água, além da presença de sais e de outros microorganismos competidores. O objetivo deste trabalho foi adicionar microcápsulas de Bifidobacterium animalis e Lactobacillus acidophilus à produção de salame tipo Italiano, avaliando seus efeitos sobre as características físico-químicas, microbiológicas e sensoriais do salame. Foram produzidos três tratamentos: T1 o controle e T2 e T3 com adição de microcápsulas de B. animalis e L. acidophilus, respectivamente. Foram realizadas análises de atividade de água, $\mathrm{pH}$, umidade, perda de peso,

\footnotetext{
Referência:

Pablo Teixeira da Silva, Leadir Lucy Martins Fries, Cristiano Ragagnin de Menezes, Juliana de Oliveira Bastos, Daniele Juçara Kleovan Lang, Janaína de Borba Braga.Avaliação do Efeito da Adição de Microcápsulas Probióticas Às Características Físico-Químicas, Microbiológicas e Sensoriais de Salame Tipo Italiano. In: Anais do 12 Congresso Latinoamericano de Microbiologia e Higiene de Alimentos - MICROAL 2014 [= Blucher Food Science Proceedings, num.1, vol.1]. São Paulo: Editora Blucher, 2014. 
contagem de coliformes à $45^{\circ} \mathrm{C}$ e Staphylococcus coagulase positiva e detecção de Salmonella sp. e o acompanhamento das culturas probióticas microencapsuladas, todas as análises ocorreram durante os 120 dias de produção; além de análise sensorial do salame após 30 dias e mensalmente até 120 dias. Os dados foram avaliados através de Análise de Variância (ANOVA) e as médias foram comparadas pelo teste de Tukey, considerando o nível de significância de 5\% (p0,05) entre os tratamentos com relação às análises físico-químicas, microbiológicas e sensoriais. Os tratamentos T2 e T3 mantiveram contagens de B. animalis e L. acidophilus acima de $8 \log$ UFC G $^{-1}$ até 53 e 48 dias, respectivamente. O estudo indica que a adição de microcápsulas de $\mathrm{B}$. animalis ou L. acidophilus à produção de salame tipo Italiano não alterou as características físico-químicas, microbiológicas e sensoriais do salame, sendo viável durante 53 e 48 dias, respectivamente.

Palavras-Chave: Bifidobacterium animalis, Lactobacillus acidophilus, microencapsulação

Agência de Fomento: 